Article

\title{
An Animal Study to Compare Hepatoprotective Effects Between Fermented Rice Bran and Fermented Rice Germ and Soybean in a Sprague-Dawley Rat Model of Alcohol-Induced Hepatic Injury
}

\author{
Hee-Young Ahn (1) and Young-Su Cho * (1) \\ Department of Biotechnology, Dong-A University, 225 Gudeok-ro Seo-gu, Busan 49315, Korea; ahnhy@dau.ac.kr \\ * Correspondence: choys@dau.ac.kr; Tel.: +82-51-200-7586; Fax: +82-51-200-7505
}

Received: 4 January 2020; Accepted: 12 February 2020; Published: 14 February 2020

check for updates

\begin{abstract}
We compared hepatoprotective effects between fermented rice bran (FRB) and fermented rice germ and soybean (FRS) in a Sprague-Dawley (SD) rat model of alcohol-induced hepatic injury (AIHI). To establish an SD rat model of AIHI, the SD rats were given $30 \%$ ethanol or water without ethanol treatment. Then, they were given $30 \%$ ethanol followed by FRB or FRS at concentrations of $15 \%$ or $30 \%$. Our results indicate that the FRB might be more effective in lowering serum levels of aspartate aminotransferase (AST), alanine aminotransferase (ALT) and alkaline phosphatase (ALP), malondialdehyde (MDA) levels in the serum and liver mitochondria, serum triglyceride levels and ALDH levels at a concentration of 15\%, serum levels of lactate dehydrogenase (LDH), GSH levels at a concentration of $30 \%$ and MDA levels in the liver homogenate and microsome, and hepatic triglyceride levels at both concentrations as compared with the FRS. It can therefore be concluded that FRB might also be considered as an alternative to FRS in improving the AIHI.
\end{abstract}

Keywords: fermented foods; rice; soybean

\section{Introduction}

Foods or beverages are fermented through regulation of microbial growth or actions of enzymes [1,2]. Thus, fermented foods are produced depending on factors such as nature of microorganisms, ingredients and environmental conditions [3-5]. In more detail, there might be different kinds of fermentation processes; these include alcoholic fermentation (yeasts), lactic acid fermentation (lactic acid bacteria) and acetic acid fermentation (Bacillus or molds) [6-10].It is well known that fermented foods can be characterized by enhanced nutritional properties and health-promoting effects [11-16].

Rice bran (RB) is a by-product of the rice milling process, and it contains diverse bioactive chemicals. Its anti-oxidative and anti-inflammatory activities have been well described in the literature $[17,18]$. $\mathrm{RB}$ is a rich source of dietary fibers and bioactive molecules, whose constituents are known to raise treatment effects of functional foods against chronic diseases $[19,20]$. Moreover, animal studies have shown that foods or beverages supplemented with RB are effective in improving dyslipidemia [21-23]. Beneficial effects of RB arising from several active compounds such as oryzanols, tocopherols, tocotrienols, phytosterols and nucleotides have been identified in rice bran [24-26]. Rodent models have demonstrated its efficacy against chronic diseases when treated with enzymes [27,28]. The effect of protein hydrolysates from RB in improving insulin resistance is one of the best examples in this case [29]. Thus, there is a growing evidence of the potential effects of RB in treating chronic diseases and their application to human health [30]. 
In an effort to improve nutraceutical activities of rice bran, several techniques have been employed. Of these, the fermentation of RB has been applied to the appropriate management of metabolic syndrome [31]. Thus, it has been reported to be effective against stress and fatigue when fermented with Saccharomyces cerevisiae and sodium dextran sulfate-induced colitis when fermented with Aspergillus oryzae [32,33]. Moreover, hepatoprotective effects of fermented rice bran (FRB) have also been described in the literature; Park et al. fermented the RB with Bacillus sp. (KCTC11351BP), Bacillus subtilis (KCTC11352BP), Bacillus sonolensis (KCTC11354BP) and Bacillus circulans (KCTC 11355BP) and then showed that the FRB was effective in protecting the liver from toxic chemicals in mice [34].

Currently, a natural ingredient extracted from fermented rice germ and soybean (FRS) is commercially available as an anti-hangover agent. It has been reported to be effective in improving alcoholic hangovers by lowering blood alcohol levels through the modulation of alcohol-metabolizing enzymes and the anti-oxidative activity [35].

In our preliminary in vitro experiment, we compared the total amount of phenolic compounds and flavonoids, the degree of free radical-scavenging activity, the effects in inhibiting lipid peroxidation in liver microsome and the antioxidative effects between the FRB and the FRS. Thus, we found that the FRB had significantly better findings compared with the FRS [36].

Given the above background, we conducted this experimental study to compare hepatoprotective effects between the FRB and the FRS in a Sprague-Dawley (SD) rat model of alcohol-induced hepatic injury (AIHI).

\section{Materials and Methods}

\subsection{Experimental Setting and Design}

The current experimental study was approved by the Institutional Animal Care and Use Committee (IACUC) of Dong-A University, Busan, Korea (IAUAC approval number: DIACUC-11-27).

For the current experiment, we used active constituents of the FRB and FRS, both of which were provided by the Korea Bio-Solutions Co. Ltd. (Busan, Korea). The FRB was characterized in our previous study; the RB was fermented using Bacillus subtilis [36]. The FRS was the RSE ${ }^{\circledR}$ (DuhanBio Co., Ltd., Seoul, Korea). In addition, we also purchased 42 white male SD rats aged four weeks (Hyochang Science Animals Co., Daegu, Korea). They were housed individually in suspended wire-mesh stainless steel cages at a room temperature of $21-24^{\circ} \mathrm{C}$ with lights on between 08:00 and 20:00. During a 1-week period prior to the experimental procedure, they were allowed free access to a semi-purified basal diet. During a 4-week experimental period, all the SD rats were evaluated daily for food intake and water consumption. They were also evaluated for body weight gain once weekly.

The SD rats were assigned to the following experimental groups:

(1) The 15\% FRB group ( $n=6)$ : The SD rats which were given $30 \%$ ethanol $(v / v)$ and $1.5 \%$ FRB $(w / w)$.

(2) The 30\% FRB group $(n=6)$ : The SD rats which were given $30 \%$ ethanol $(v / v)$ and $3.0 \%$ FRB $(w / w)$.

(3) The $15 \%$ FRS group $(n=6)$ : The SD rats which were given $30 \%$ ethanol $(v / v)$ and $1.5 \%$ FRS $(w / w)$.

(4) The 30\% FRS group $(n=6)$ : The SD rats which were given $30 \%$ ethanol $(v / v)$ and $3.0 \%$ FRS $(w / w)$.

\subsection{Experimental Procedures}

\subsubsection{Validation of an SD Rat Model of AIHI}

To establish an SD rat model of AIHI, the experimental rats were given $30 \%$ ethanol or water without ethanol treatment. Then, they were sacrificed by withdrawing blood from the abdominal aorta under light diethyl ether anesthesia. To examine whether we successfully established an SD rat model of AIHI, we performed histopathologic examinations of the liver sample. To do this, the liver sample was fragmented and then fixed using $4 \%$ paraformaldehyde and $0.1 \mathrm{M}$ phosphate buffered saline $(\mathrm{pH}=7.4)$. After that, it was embedded in a paraffin block and then sectioned at a thickness of approximately $6 \mu \mathrm{m}$. This was followed by staining with a hematoxylin and eosin dye. Then, 
we examined histopathologic specimens using a light microscope (Olympus BS41; Olympus Co., Tokyo, Japan). Thus, we compared the number and volume of fat globules between the SD rats ingesting $30 \%$ ethanol and those ingesting water without ethanol treatment.

\subsubsection{Quantification of Serum Hepatic Enzymes}

After sacrifice, the SD rats were evaluated for the collection of serum samples. Then, the samples were collected, centrifuged at $1026 \times \mathrm{g}$ for $15 \mathrm{~min}$ at $4{ }^{\circ} \mathrm{C}$ and stored at $-70{ }^{\circ} \mathrm{C}$ for further laboratory procedure.

We measured serum levels of hepatic enzymes such as alanine aminotransferase (ALT), aspartate aminotransferase (AST), alkaline phosphatase (ALP), $\gamma$-glutamyltranspeptidase $(\gamma$-GTP) and lactate dehydrogenase (LDH) using the Chemiclinical Chemistry Analyzer (Samkwang Medical Laboratories, Seoul, Korea).

\subsubsection{Preparation of Liver Homogenate Fractions}

After the SD rats were sacrificed, their liver was extracted and then perfused in situ with saline $(8.5 \mathrm{~g} \mathrm{NaCl} / \mathrm{L})$. Then, it was weighed, frozen immediately in liquid nitrogen and stored at $-70{ }^{\circ} \mathrm{C}$ for further laboratory procedure. As previously described, subcellular liver fractions were prepared [37]. In detail, the liver was homogenized in nine volumes of ice-cold potassium phosphate buffer $(0.1 \mathrm{M}$ potassium phosphate containing $1 \mathrm{mM}$ sodium EDTA and $1 \mathrm{mM}$ dithiothreitol, $\mathrm{pH}=7.4$ ) using an IKA-ULTRA-TURRAX T25 basic homogenizer (Ika-Werke GmBH and Co., Staufen, Germany). The homogenate was centrifuged at $800 \times g$ for $10 \mathrm{~min}$, and the supernatant was centrifuged at $10,000 \times g$ for $20 \mathrm{~min}$. The pellet was resuspended in buffer as the mitochondrial fraction. The supernatant was further centrifuged at $105,000 \times g$ for $60 \mathrm{~min}$. The resulting clear supernatant was used as the cytosolic fraction. The precipitate was resuspended in the same buffer and then centrifuged again at $105,000 \times g$ for $60 \mathrm{~min}$. The pellet was resuspended in buffer as the microsome fraction. Then, subcellular fractions of mitochondria, cytosol and microsomes were stored at $-70{ }^{\circ} \mathrm{C}$ for further laboratory procedure.

\subsubsection{Quantification of Lipid Peroxidation}

The concentration of lipid peroxides was measured based on thiobarbituric acid reactive substances (TBARS) in both hepatic subcellular fractions and serum, as previously described [38-40]. The reaction mixture was a solution containing homogenates, subcellular fractions and thiobarbituric acid (TBA). Then, it was incubated in boiling water for $30 \mathrm{~min}$. After centrifugation at $1000 \times g$ for $10 \mathrm{~min}$, its upper layer was measured for the absorbance at a wavelength of $532 \mathrm{~nm}$. The concentration of TBARS was expressed as $\mathrm{nM}$ of malondialdehyde (MDA) per $\mathrm{g}$ liver or $\mathrm{mL}$ serum.

\subsubsection{Quantification of Hepatic Enzymes Involved in The Alcohol Metabolism}

The activity of ADH was measured using a spectrophotometry based on its indicator, the degree of the conversion of NAD (Sigma Chemical Co., Louis, MO, USA) to nicotinamide adenine dinucleotide dehydrogenase (NADH), as described previously [41,42]. In addition, the activity of ALDH was measured using the methods of Koivula and Koivusalo [43,44]. Then, on noticing the reaction of enzymes, we measured the absorbance at a wavelength of $340 \mathrm{~nm}$ for $5 \mathrm{~min}$.

\subsubsection{Western Blot Analysis}

For the Western blot analysis, we isolated the protein of the liver homogenate fraction containing ADH or ALDH using the $10 \%$ sodum dodecyl sulfate (SDS)-polyacryamide gel electrophoresis (20 and $100 \mu \mathrm{g}$ for ADH and ALDH proteins per lane, respectively), as described previously [45]. The protein samples were transferred electrophoretically to a nitrocellulose membrane at $4{ }^{\circ} \mathrm{C}$ for $16 \mathrm{~h}$ at a constant current of $300 / 240 \mathrm{~mA} / \mathrm{cm}^{2}$, and non-specific binding was inhibited using a blocking buffer $(10 \%$ fat-free milk in Tris-Buffered Saline and Tween 20 (TBST) buffer) at room temperature for $1 \mathrm{~h}$. The membrane 
was repeatedly washed with the TBST buffer $(10 \mathrm{mM}$ Tris, $\mathrm{pH}=7.5,100 \mathrm{mM} \mathrm{NaCl}, 0.1 \%$ Tween 20$)$ for $5 \mathrm{~min}$. Then, it was probed with a rabbit ADH- or ALDH1A1-conjugated antibody (diluted at a ratio of 1:1000, Abcam, UK) overnight at $4{ }^{\circ} \mathrm{C}$. After the primary antibody reaction, the membrane sample was washed with the TBST buffer. Then, it was incubated with an anti-mouse or anti-rabbit IgG-HRP (diluted at a ratio of 1:5000, DBUSA) at room temperature for $1 \mathrm{~h}$. Equivalent loading of the protein samples was confirmed by re-probing membranes with mouse monoclonal GADPH IgG (diluted at a ratio of 1:1000; Milford). Proteins in the nitrocellulose membranes were detected by using the image analysis method using the SuperSignal West Pico Chemiluminescent Substrate and densitometrically quantified. The relative density of the ADH or ALDH protein band in each reaction was quantified by a densitometer (Lumi-Imager F1, Roche, Bazel, Switzerland).

\subsubsection{Quantification of GSH}

The concentration of $\gamma$-glutamyl-cysteinyl-glycine (glutathione, GSH) was determined, as previously described [46-48]. A 0.2-mL aliquot of liver homogenate was well mixed with EDTA solution $1.8 \mathrm{~mL}$. This was followed by the addition of precipitating reagent $3.0 \mathrm{~mL}(1.67 \mathrm{~g}$ of metaphosphoric acid, EDTA disodium salt $0.2 \mathrm{~g}$, sodium chloride $30 \mathrm{~g}$ and distilled water $1 \mathrm{~L}$ ). The sample was preserved at $4{ }^{\circ} \mathrm{C}$ for $5 \mathrm{~min}$ and then centrifuged at $3000 \times \mathrm{g}$ for $5 \mathrm{~min}$. A $2-\mathrm{mL}$ of the supernatant was mixed with $0.3 \mathrm{M}$ disodium hydrogen phosphate solution $4 \mathrm{~mL}$ and 5,5'-dithiobis (2-nitrobenzoic acid) reagent $0.1 \mathrm{~mL}$. This was followed by the spectrophotometry at a wavelength of $412 \mathrm{~nm}$. Finally, the total concentration of GSH was expressed as nM per $\mathrm{g}$ liver.

\subsection{Statistical Analysis}

All data was expressed as mean \pm SE (SE: standard error) and was analyzed using one-way analysis of variance (ANOVA). Statistical analysis was done using the Duncan's new multiple-range test. A $p$-value of $<0.05$ was considered statistically significant.

\section{Results}

\subsection{Validation of an SD Model of AIHI}

On histopathologic examinations of the liver samples, the number and volume of fat globules were increased in the SD rats ingesting 30\% ethanol as compared with those ingesting water without ethanol treatment (Figure 1). This confirms that we successfully established an SD model of AIHI.

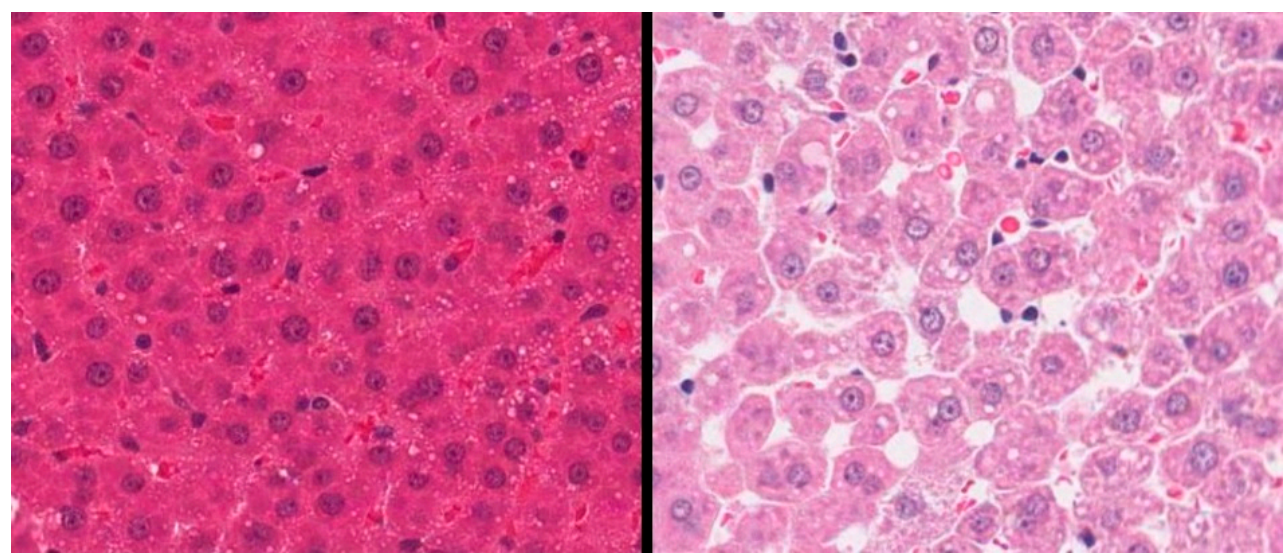

Figure 1. Validation of a Sprague-Dawley (SD) rat model of alcohol-induced hepatic injury on histopathologic examinations. The number and volume of fat globules were increased in (right) the SD rats ingesting 30\% ethanol as compared with (left) those ingesting water without ethanol treatment (Hematoxylin \& eosin, $\times 400$ ). 


\subsection{Effects of FRB and FRS on Serum Levels of ALT, AST, ALP, $\gamma$-GTP and LDH}

Serum levels of AST, ALT and ALP were significantly lower in the $15 \%$ FRB and 30\% FRB group compared with the 15\% FRS and 30\% FRS group in the corresponding order $(p<0.05)$. Moreover, serum levels of $\gamma$-GTP were significantly higher in the 15\% FRB group as compared with the $15 \%$ FRS group, but were significantly lower in the $30 \%$ FRB group compared with the $30 \%$ FRS group $(p<0.05)$. Furthermore, serum levels of LDH were significantly lower in the 15\% FRB group as compared with the $15 \%$ FRS group $(p<0.05)$, but there were no significant differences between the $30 \%$ FRB group and the $30 \%$ FRS group $(p>0.05$ ) (Figure 2). These results indicate that the FRB might be more effective in lowering serum levels of AST, ALT and ALP at a concentration of $15 \%$ and those of LDH at a concentration of $30 \%$ compared with the FRS.
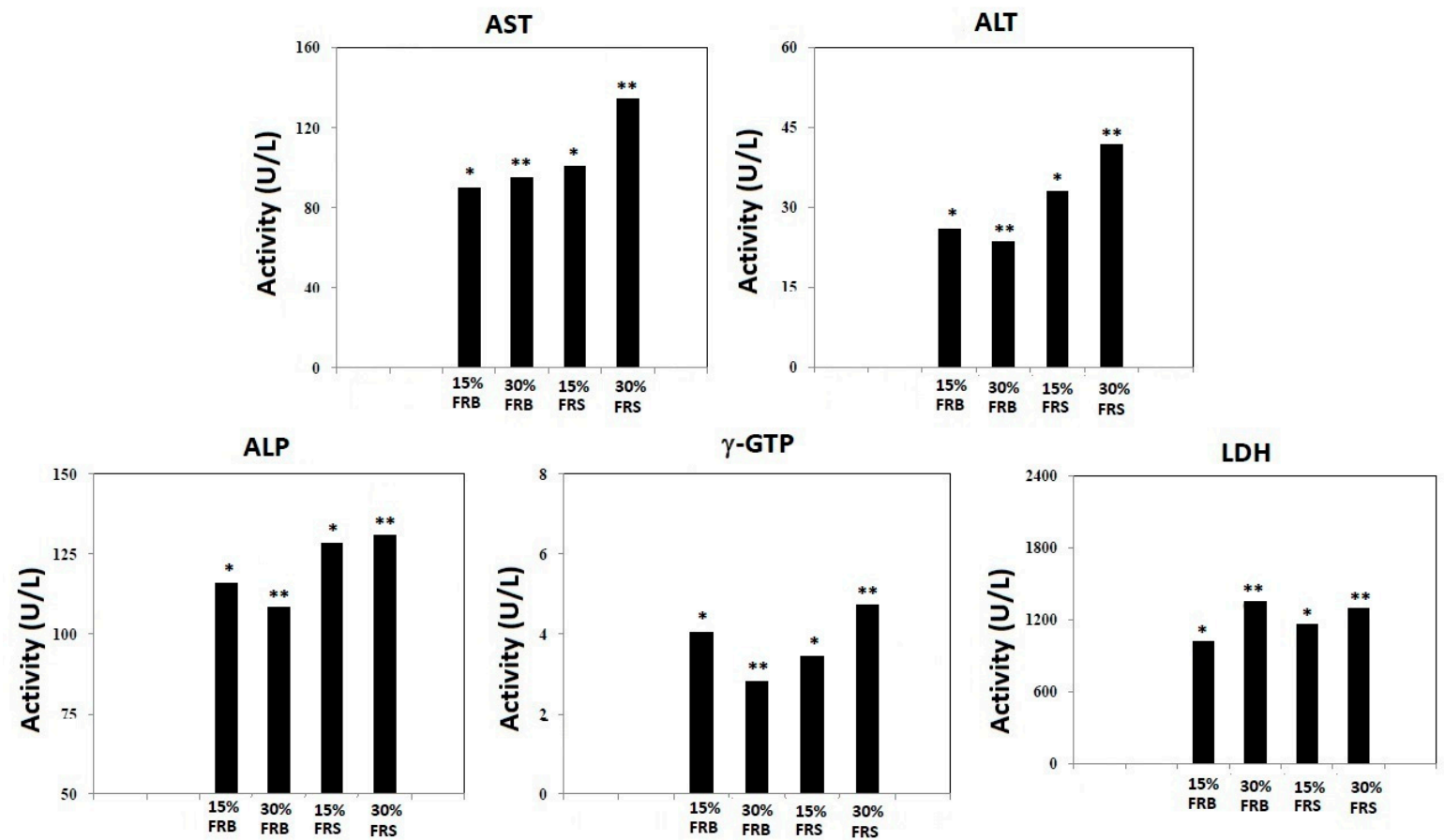

Figure 2. The effects of fermented rice bran (FRB) and fermented rice germ and soybean (FRS) on serum levels of aspartate aminotransferase (AST), alanine aminotransferase (ALT), alkaline phosphatase (ALP), $\gamma$-glutamyltranspeptidase $(\gamma$-GTP) and lactate dehydrogenase (LDH). * Statistical significance at $p<0.05$. ${ }^{* *}$ Statistical significance at $p<0.05$.

\subsection{Effects of FRB and FRS on TBARS}

MDA levels in the liver homogenate and microsome were significantly lower in the $15 \%$ FRB and $30 \%$ FRB group compared with the 15\% FRS and 30\% FRS group in the corresponding order $(p<0.05)$. Moreover, MDA levels in the serum and liver mitochondria were also significantly lower in the $30 \%$ FRB group compared with the $30 \%$ FRS group $(p<0.05)$, but there were no significant differences between the $15 \%$ FRB group and the $15 \%$ FRS group $(p>0.05)$ (Figure 3). These results indicate that the FRB might be more effective in lowering MDA levels in the liver homogenate and microsome at both concentrations as compared with the FRS. Moreover, it can also be inferred that the FRB might be more effective in lowering MDA levels in the serum and liver mitochondria at a concentration of $15 \%$ as compared with the FRS. 

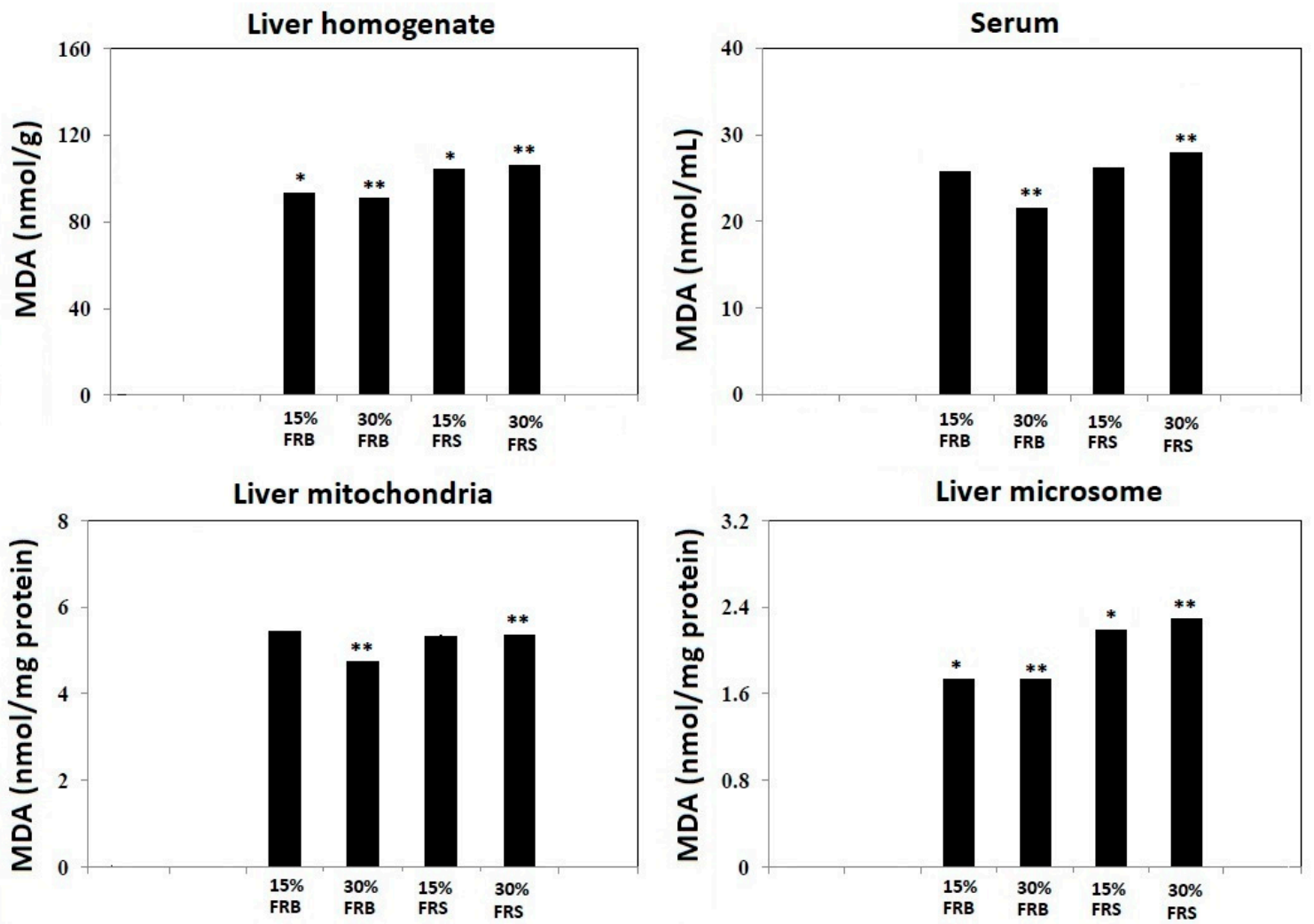

Figure 3. Effects of fermented rice bran (FRB) and fermented rice germ and soybean (FRS) on thiobarbituric acid reactive substances (TBARS) in the liver and serum. * Statistical significance at $p<0.05$. ${ }^{* *}$ Statistical significance at $p<0.05$.

\subsection{Effects of FRB and FRS on GSH}

There were no significant differences in GSH levels in the liver between the 15\% FRB group and the $15 \%$ FRS group $(p>0.05)$. However, they were significantly lower in the serum in the $30 \%$ FRB group compared with the $30 \%$ FRS group $(p<0.05)$ (Figure 4 ). These results indicate that the FRB might be more effective in lowering GSH levels in the serum at a concentration of $30 \%$ compared with the FRS.
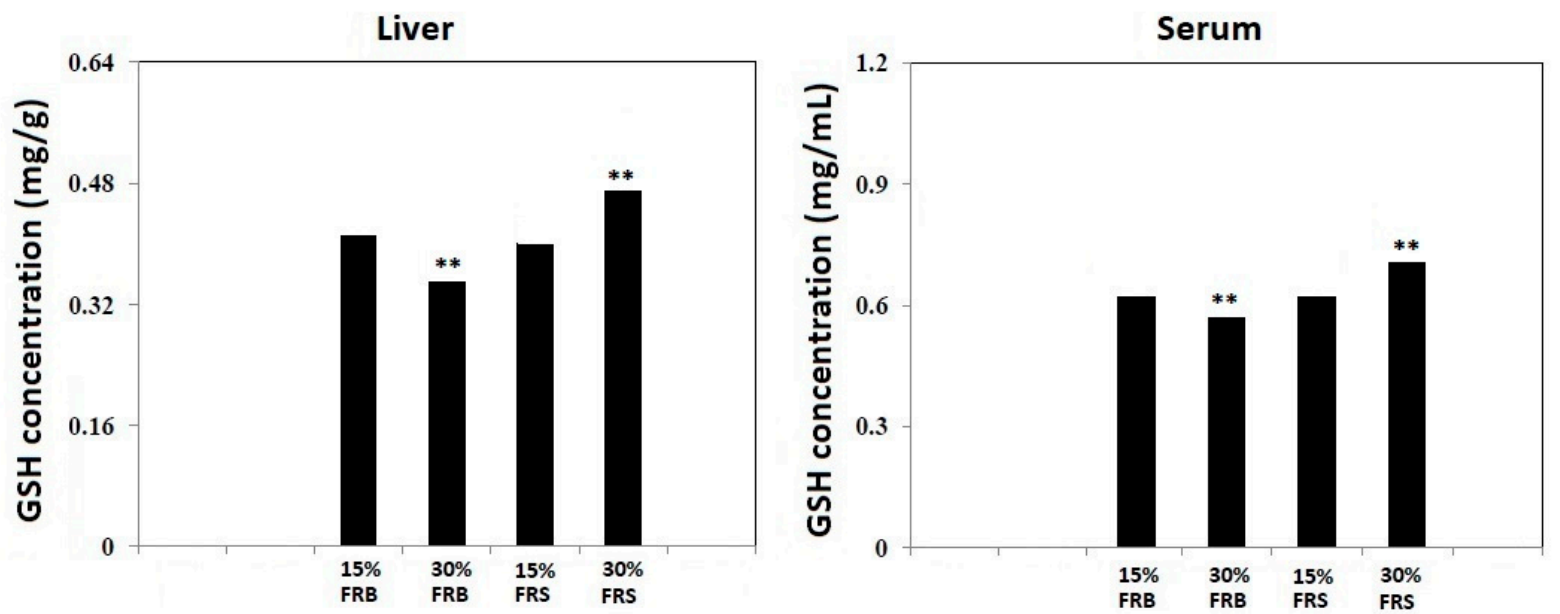

Figure 4. Effects of fermented rice bran (FRB) and fermented rice germ and soybean (FRS) on glutathione concentrations in the liver and serum. ${ }^{*}$ Statistical significance at $p<0.05$. ${ }^{*}$ Statistical significance at $p<0.05$. 


\subsection{Effects of FRB and FRS on Levels of Triglyceride}

Serum triglyceride levels were significantly lower in the 15\% FRB group compared with the $15 \%$ FRS group and higher in the 30\% FRB group compared with the 30\% FRS group $(p<0.05)$. Moreover, hepatic triglyceride levels were significantly lower the 15\% FRB and 30\% FRB group compared with the $15 \%$ FRS and $30 \%$ FRS group $(p<0.05)$ (Figure 5). These results indicate that the FRB might be more effective in lowering serum triglyceride levels at a concentration of $15 \%$ and hepatic triglyceride levels at both concentrations compared with the FRS.
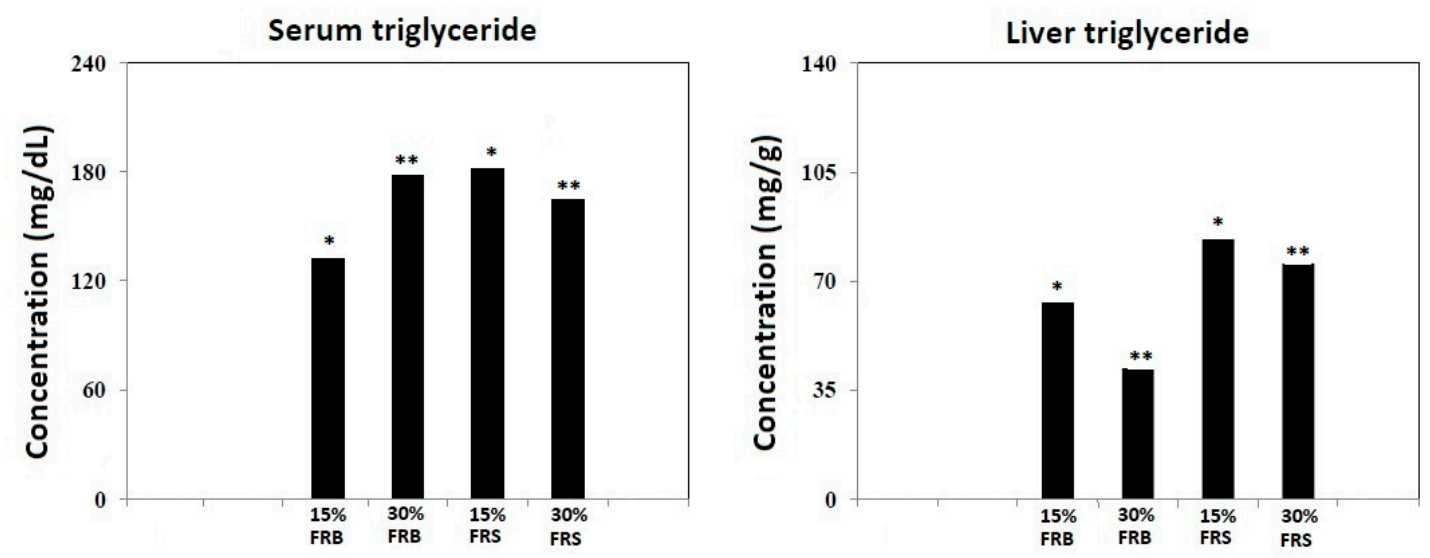

Figure 5. Effects of fermented rice bran (FRB) and fermented rice germ and soybean (FRS) on triglyceride concentrations in the liver and serum. ${ }^{*}$ Statistical significance at $p<0.05$. ${ }^{* *}$ Statistical significance at $p<0.05$.

\subsection{Effects of FRB and FRS on Levels of ADH and ALDH}

ADH levels were significantly higher in the 15\% FRB and 30\% FRB group as compared with the $15 \%$ FRS and 30\% FRS group $(p<0.05)$. Moreover, ALDH levels were significantly lower in the $15 \%$ FRB group compared with the 15\% FRS group and higher in the 30\% FRB group compared with the $30 \%$ FRS group $(p<0.05$ )(Figure 6). These results indicate that the FRB might be more effective in lowering ALDH levels at a concentration of $15 \%$ compared with the FRS.

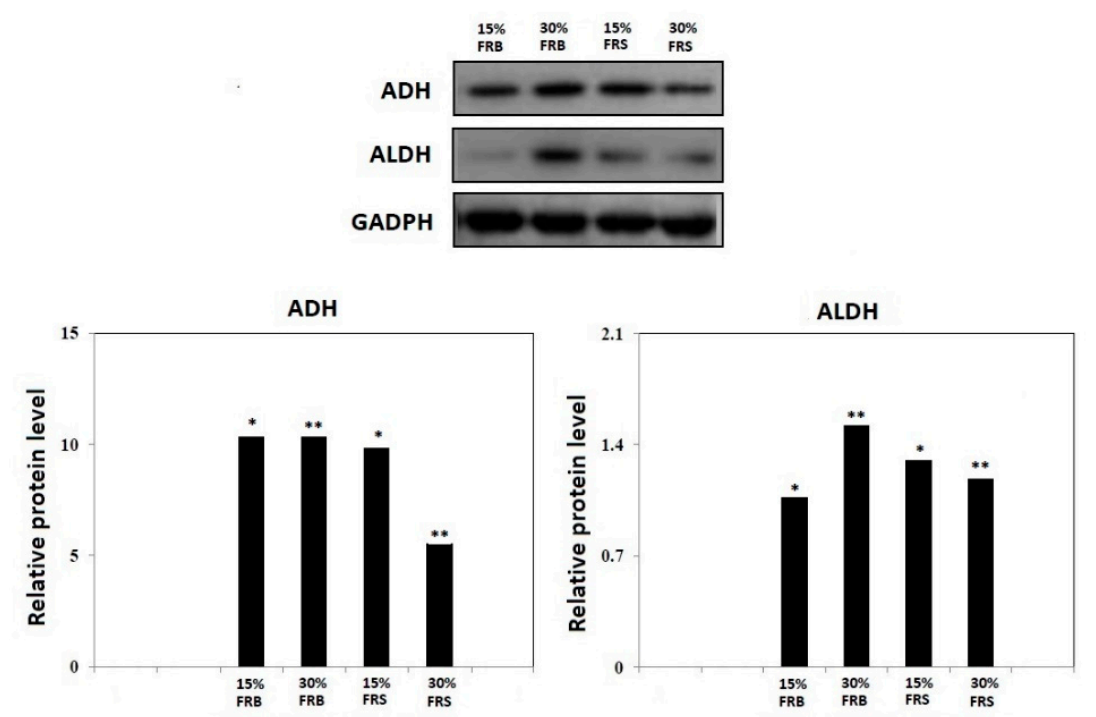

Figure 6. Effects of fermented rice bran (FRB) and fermented rice germ and soybean (FRS) on the activity of alcohol dehydrogenase (ADH) and acetaldehyde dehydrogenase (ALDH) in the liver. Abbreviations: GAPDH, glyceraldehyde-3-phosphate dehydrogenase. * Statistical significance at $p<0.05$. ${ }^{* *}$ Statistical significance at $p<0.05$. 


\section{Discussion}

Fermentation is the key process where bread, cheese and alcoholic beverages are produced. It not only improves the usability of nutrients, texture and taste but also increases the flavor of foods [49,50]. It involves microbes and thereby produces compounds that inhibit the growth of contaminating microorganisms; these include organic acids, ethanol, short-chain fatty acids, and bacteriocins [51]. According to several previously published studies, fermented foods have beneficial effects on the gastrointestinal tract system. Moreover, recent studies have shown that supplementation of fermented foods had beneficial effects in improving symptoms of type 2 diabetes mellitus, impaired glucose metabolism, obesity, irritable bowel syndrome, hyperlipidemia, hypertension and osteoporosis [2,3,7,51-57].

Antioxidative compounds are also produced during fermentation [58]. Fermented soybean is incubated with Aspergillus oryzae, Bacillus subtilis and Rhizopus oligosporus, and it has a higher degree of anti-lipid peroxidative effects compared with steam soybeans $[56,59,60]$. Its active constituents include free isoflavones, such as daidzein and genistein, which are considered major antioxidants [61-63].

Our results indicate that the FRB might be more effective in lowering serum levels of AST, ALT and ALP at a concentration of $15 \%$ and those of $\mathrm{LDH}$ at a concentration of $30 \%$ compared with the FRS. This is in agreement with previously published studies showing that the FRB had a positive effect on serum levels of hepatic enzymes [30,31,64-73].

According to our experiment, the FRB might be more effective in lowering MDA levels in the liver homogenate and microsome at both concentrations compared with the FRS. Moreover, it can also be inferred that the FRB might be more effective in lowering MDA levels in the serum and liver mitochondria at a concentration of $15 \%$ compared with the FRS. Our results are in agreement with previous studies showing that the FRB is useful to lower both MDA levels [74-78].

We found that the FRB might be more effective in lowering GSH levels in the serum at a concentration of 30\% compared with the FRS. This is also seen in prior publications [79-84].

Levels of lipid peroxides and GSH are increased and decreased, respectively, in association with chronic alcohol consumption [85-87]. Moreover, levels of TBARS are elevated in association with acute or chronic alcohol consumption, which is followed by the involvement of aldehyde in increasing the synthesis of free radicals [86]. With the actions of aldehyde on xanthine oxidase in the cytoplasm, there is an increase in the synthesis of superoxidase. This eventually leads to damages to the liver tissue [88]. Furthermore, reactive oxygen species are increasingly formed in association with the chronic alcohol consumption. This is responsible for the inactivation of hepatic enzymes, followed by the structure and functions of mitochondria [89-91]. Our results showed that there was an increase in levels of lipid peroxides in fractions of homogenate, mitochondria and microsome in the liver, which is in agreement with previously published studies [92-94]. This also leads to the speculation that lower levels of lipid peroxides in the liver and serum might have a relationship with elevated levels of anti-oxidants [72].

Our results indicate that the FRB might be more effective in lowering serum triglyceride levels at a concentration of $15 \%$ and hepatic triglyceride levels at both concentrations compared with the FRS. Moreover, we found that the FRB might be more effective in lowering ALDH levels at a concentration of $15 \%$ compared with the FRS. These results are in agreement with previous studies $[64,65,67,70,79,95-97]$.

\section{Conclusions}

Based on our results, it can be concluded that the FRB might also be considered as an alternative to the FRS in improving the AIHI, but this deserves further experimental and clinical studies.

Author Contributions: Conceptualization, H.-Y.A. and Y.-S.C.; methodology, H.-Y.A.; software, H.-Y.A.; validation, H.-Y.A. and Y.-S.C.; formal analysis, H.-Y.A.; investigation, H.-Y.A.; resources, H.-Y.A.; data curation, H.-Y.A.; writing-original draft preparation, H.-Y.A. and Y.-S.C.; writing-review and editing, H.-Y.A. and Y.-S.C.; visualization, H.-Y.A.; supervision, H.-Y.A.; project administration, Y.-S.C. All authors have read and agreed to the published version of the manuscript. 
Funding: This work was supported by the Technological Innovation R\&D Program (S2148298) funded by the Small and Medium Business Administration (SMBA, Korea).

Conflicts of Interest: The author declares no conflict of interest.

\section{References}

1. Raveendran, S.; Parameswaran, B.; Ummalyma, S.B.; Abraham, A.; Mathew, A.K.; Madhavan, A.; Rebello, S.; Pandey, A. Applications of Microbial Enzymes in Food Industry. Food Technol. Biotechnol. 2018, 56, 16-30. [CrossRef] [PubMed]

2. Melini, F.; Melini, V.; Luziatelli, F.; Ficca, A.G.; Ruzzi, M. Health-Promoting Components in Fermented Foods: An Up-to-Date Systematic Review. Nutrients 2019, 11, 1189. [CrossRef] [PubMed]

3. Dimidi, E.; Cox, S.R.; Rossi, M.; Whelan, K. Fermented Foods: Definitions and Characteristics, Impact on the Gut Microbiota and Effects on Gastrointestinal Health and Disease. Nutrients 2019, 11, 1806. [CrossRef] [PubMed]

4. Anal, A.K. Quality Ingredients and Safety Concerns for Traditional Fermented Foods and Beverages from Asia: A Review. Fermentation 2019, 5, 8. [CrossRef]

5. Arena, M.P.; Russo, P.; Spano, G.; Capozzi, V. From Microbial Ecology to Innovative Applications in Food Quality Improvements: The Case of Sourdough as a Model Matrix. J Multidiscip. Sci. J. 2020, 3, 9-19. [CrossRef]

6. Marco, M.L.; Heeney, D.; Binda, S.; Cifelli, C.J.; Cotter, P.D.; Foligné, B.; Gänzle, M.; Kort, R.; Pasin, G.; Pihlanto, A.; et al. Health benefits of fermented foods: Microbiota and beyond. Curr. Opin. Biotechnol. 2017, 44, 94-102. [CrossRef]

7. Gille, D.; Schmid, A.; Walther, B.; Vergères, G. Fermented Food and Non-Communicable Chronic Diseases: A Review. Nutrients 2018, 10, 448. [CrossRef]

8. Russo, P.; Fares, C.; Longo, A.; Spano, G.; Capozzi, V. Lactobacillus plantarum with Broad Antifungal Activity as a Protective Starter Culture for Bread Production. Foods 2017, 6, 110. [CrossRef]

9. Berbegal, C.; Garofalo, C.; Russo, P.; Pati, S.; Capozzi, V.; Spano, G. Use of Autochthonous Yeasts and Bacteria in Order to Control Brettanomyces bruxellensis in Wine. Fermentation 2017, 3, 65. [CrossRef]

10. Lee, S.; Lee, J.-A.; Park, G.-G.; Jang, J.-K.; Park, Y.-S. Semi-Continuous Fermentation of Onion Vinegar and Its Functional Properties. Molecules 2017, 22, 1313. [CrossRef]

11. Şanlier, N.; Gökcen, B.B.; Sezgin, A.C. Health benefits of fermented foods. Crit. Rev. Food Sci Nutr. 2019, 59, 506-527. [CrossRef] [PubMed]

12. Tagliazucchi, D.; Martini, S.; Solieri, L. Bioprospecting for Bioactive Peptide Production by Lactic Acid Bacteria Isolated from Fermented Dairy Food. Fermentation 2019, 5, 96. [CrossRef]

13. Borresen, E.C.; Henderson, A.J.; Kumar, A.; Weir, T.L.; Ryan, E.P. Fermented foods: Patented approaches and formulations for nutritional supplementation and health promotion. Recent Pat. Food Nutr. Agric. 2012, 4, 134-140. [CrossRef] [PubMed]

14. de Marco Castro, E.; Shannon, E.; Abu-Ghannam, N. Effect of Fermentation on Enhancing the Nutraceutical Properties of Arthrospira platensis (Spirulina). Fermentation 2019, 5, 28. [CrossRef]

15. Verardo, V.; Gómez-Caravaca, A.M.; Tabanelli, G. Bioactive Components in Fermented Foods and Food By-Products. Foods 2020, 9, 153. [CrossRef]

16. Capozzi, V.; Fragasso, M.; Romaniello, R.; Berbegal, C.; Russo, P.; Spano, G. Spontaneous Food Fermentations and Potential Risks for Human Health. Fermentation 2017, 3, 49. [CrossRef]

17. Saji, N.; Francis, N.; Blanchard, C.L.; Schwarz, L.J.; Santhakumar, A.B. Rice Bran Phenolic Compounds Regulate Genes Associated with Antioxidant and Anti-Inflammatory Activity in Human Umbilical Vein Endothelial Cells with Induced Oxidative Stress. Int. J. Mol. Sci. 2019, 20, 4715. [CrossRef]

18. Islam, M.S.; Nagasaka, R.; Ohara, K.; Hosoya, T.; Ozaki, H.; Ushio, H.; Hori, M. Biological abilities of rice bran-derived antioxidant phytochemicals for medical therapy. Curr. Top. Med. Chem. 2011, 11, 1847-1853. [CrossRef]

19. Quirós-Sauceda, A.E.; Palafox-Carlos, H.; Sáyago-Ayerdi, S.G.; Ayala-Zavala, J.F.; Bello-Perez, L.A.; Alvarez-Parrilla, E.; De La Rosa, L.A.; González-Córdova, A.F.; González-Aguilar, G.A. Dietary fiber and phenolic compounds as functional ingredients: Interaction and possible effect after ingestion. Food Funct. 2014, 5, 1063-1072. [CrossRef] 
20. Azizah, A.H.; Luan, Y.S. Functional properties of dietary fibre prepared from defatted rice bran. Food Chem. 2000, 68, 15-19.

21. Kahlon, T.S.; Chow, F.I.; Sayre, R.N.; Betschart, A.A. Cholesterol-lowering in hamsters fed rice bran at various levels, defatted rice bran and rice bran oil. J. Nutr. 1992, 122, 513-519. [CrossRef] [PubMed]

22. Newman, R.K.; Betschart, A.A.; Newman, C.W.; Hofer, P.J. Effect of full-fat or defatted rice bran on serum cholesterol. Plant Foods Hum. Nutr. 1992, 42, 37-43. [CrossRef] [PubMed]

23. Nicolosi, R.J.; Ausman, L.M.; Hegsted, D.M. Rice bran oil lowers serum total and low density lipoprotein cholesterol and apo B levels in nonhuman primates. Atherosclerosis 1991, 88, 133-142. [CrossRef]

24. Shirakawa, H.; Shimeno, T.; Koseki, T.; Shiono, Y.; Murayama, T.; Hatakeyama, E.; Komai, M. Adenosine, an identified active component from the Driselase-treated fraction of rice bran, is effective at improving metabolic syndrome in stroke-prone spontaneously hypertensive rats. J. Agric. Food Chem. 2009, 57, 2558-2564.

25. Palou, M.; Sánchez, J.; García-Carrizo, F.; Palou, A.; Picó, C. Pectin supplementation in rats mitigates age-related impairment in insulin and leptin sensitivity independently of reducing food intake. Mol. Nutr. Food Res. 2015, 59, 2022-2033. [CrossRef] [PubMed]

26. Wang, O.; Liu, J.; Cheng, Q.; Guo, X.; Wang, Y.; Zhao, L.; Zhou, F.; Ji, B. Effects of ferulic acid and $\gamma$-oryzanol on high-fat and high-fructose diet-induced metabolic syndrome in rats. PLoS ONE 2015, 10, e0118135. [CrossRef]

27. Candiracci, M.; Justo, M.L.; Castaño, A.; Rodriguez-Rodriguez, R.; Herrera, M.D. Rice bran enzymatic extract-supplemented diets modulate adipose tissue inflammation markers in Zucker rats. Nutrition 2014, 30, 466-472. [CrossRef]

28. Justo, M.L.; Candiracci, M.; Dantas, A.P.; de Sotomayor, S.M.A.; Parrado, J.; Vila, E.; Herrera, M.D.; Rodriguez-Rodriguez, R. Rice bran enzymatic extract restores endothelial function and vascular contractility in obese rats by reducing vascular inflammation and oxidative stress. J. Nutr. Biochem. 2013, 24, 1453-1461. [CrossRef]

29. Boonloh, K.; Kukongviriyapan, V.; Kongyingyoes, B.; Kukongviriyapan, U.; Thawornchinsombut, S.; Pannangpetch, P. Rice Bran Protein Hydrolysates Improve Insulin Resistance and Decrease Pro-inflammatory Cytokine Gene Expression in Rats Fed a High Carbohydrate-High Fat Diet. Nutrients 2015, 7, 6313-6329. [CrossRef]

30. Ryan, E.P.; Heuberger, A.L.; Weir, T.L.; Barnett, B.; Broeckling, C.D.; Prenni, J.E. Rice bran fermented with saccharomyces boulardii generates novel metabolite profiles with bioactivity. J. Agric. Food Chem. 2011, 59, 1862-1870. [CrossRef]

31. Alauddin, M.; Shirakawa, H.; Koseki, T.; Kijima, N.; Budijanto, S.; Islam, J.; Goto, T.; Komai, M. Fermented rice bran supplementation mitigates metabolic syndrome in stroke-prone spontaneously hypertensive rats. BMC Complement Altern. Med. 2016, 16, 442. [CrossRef] [PubMed]

32. Kim, K.M.; Yu, K.W.; Kang, D.H.; Suh, H.J. Anti-stress and anti-fatigue effect of fermented rice bran. Phytother. Res. 2002, 16, 700-702. [CrossRef] [PubMed]

33. Kataoka, K.; Ogasa, S.; Kuwahara, T.; Bando, Y.; Hagiwara, M.; Arimochi, H.; Nakanishi, S.; Iwasaki, T.; Ohnishi, Y. Inhibitory effects of fermented brown rice on induction of acute colitis by dextran sulfate sodium in rats. Dig. Dis. Sci. 2008, 53, 1601-1608. [CrossRef] [PubMed]

34. Park, S.; Lee, S.; Nam, Y.; Yi, S.; Seo, M.; Lim, S. Hepatoprotective Effect of Fermented Rice Bran against Carbon Tetrachloride-Induced Toxicity in Mice. Food Sci. Biotechnol. 2014, 23, 165-171. [CrossRef]

35. Lee, H.S.; Song, J.; Kim, T.M.; Joo, S.S.; Park, D.; Jeon, J.H.; Shin, S.; Park, H.K.; Lee, W.K.; Ly, S.Y.; et al. Effects of a preparation of combined glutathione-enriched yeast and rice embryo/soybean extracts on ethanol hangover. J. Med. Food 2009, 12, 1359-1367. [CrossRef]

36. Ahn, H.; Choe, D.; Kim, B.; Lee, J.; Cho, Y. Bioactive Materials and Antioxidant Properties of Fermented Rice-bran Extract. J. Life Sci. 2015, 25, 1014-1020. [CrossRef]

37. Féher, J.; Lengyel, G. Silymarin in the prevention and treatment of liver diseases and primary liver cancer. Curr. Pharm. Biotechnol. 2012, 13, 210-217. [CrossRef]

38. Comar, J.F.; de Sá-Nakanishi, A.B.; de Oliveira, A.L.; Marques, N.W.M.; Bersani, A.C.A.; Ishii, I.E.L.; Peralta, R.M.; Bracht, A. Oxidative state of the liver of rats with adjuvant-induced arthritis. Free Radic. Biol. Med. 2013, 58, 144-153. [CrossRef] 
39. Trejo-Solís, C.; Chagoya, D.S.V.; Aranda-Fraustro, A.; Sánchez-Sevilla, L.; Gómez-Ruíz, C.; Hernández-Muñoz, R. Inhibitory effect of vitamin e administration on the progression of liver regeneration induced by partial hepatectomy in rats. Lab. Investig. 2003, 83, 1669-1679. [CrossRef]

40. Hernández-Muñoz, R.; Olguín-Martínez, M.; Aguilar-Delfín, I.; Sánchez-Sevilla, L.; García-García, N.; Díaz-Muñoz, M. Oxidant status and lipid composition of erythrocyte membranes in patients with type 2 diabetes, chronic liver damage, and a combination of both pathologies. Oxid. Med. Cell Longev. 2013, 2013, 657387. [CrossRef]

41. Josan, S.; Xu, T.; Yen, Y.F.; Hurd, R.; Ferreira, J.; Chen, C.H.; Mochly-Rosen, D.; Pfefferbaum, A.; Mayer, D.; Spielman, D. In vivo measurement of aldehyde dehydrogenase-2 activity in rat liver ethanol model using dynamic MRSI of hyperpolarized [1-(13) C]pyruvate. NMR Biomed. 2013, 26, 607-612. [PubMed]

42. Gong, J.; Gan, J.; Masson, E.; Syed, S.; Xia, Y.Q.; Williams, D.; Pursley, J.; Jemal, M.; Humphreys, W.G.; Iyer, R.A. Metabolic chiral inversion of brivanib and its relevance to safety and pharmacology. Drug Metab. Dispos. 2012, 40, 2374-2380. [CrossRef] [PubMed]

43. Yuasa, K.; Omori, K.; Yanaka, N. Binding and phosphorylation of a novel male germ cell-specific cGMP-dependent protein kinase-anchoring protein by cGMP-dependent protein kinase Ialpha. J. Biol. Chem. 2000, 275, 4897-4905. [CrossRef] [PubMed]

44. Rahman, I.; Kode, A.; Biswas, S.K. Assay for quantitative determination of glutathione and glutathione disulfide levels using enzymatic recycling method. Nat. Protoc. 2006, 1, 3159-3165. [CrossRef] [PubMed]

45. Lu, S.C. Regulation of glutathione synthesis. Mol. Aspects Med. 2009, 30, 42-59. [CrossRef] [PubMed]

46. Steele, M.L.; Fuller, S.; Patel, M.; Kersaitis, C.; Ooi, L.; Münch, G. Effect of Nrf2 activators on release of glutathione, cysteinylglycine and homocysteine by human U373 astroglial cells. Redox. Biol. 2013, 1, 441-445. [CrossRef]

47. Rusyn, I.; Bataller, R. Alcohol and toxicity. J. Hepatol. 2013, 59, 387-388. [CrossRef]

48. Molina, P.E.; Gardner, J.D.; Souza-Smith, F.M.; Whitaker, A.M. Alcohol abuse: Critical pathophysiological processes and contribution to disease burden. Physiology 2014, 29, 203-215. [CrossRef]

49. Leyva Salas, M.; Mounier, J.; Valence, F.; Coton, M.; Thierry, A.; Coton, E. Antifungal microbial agents for food biopreservation-A review. Microorganisms 2017, 5, 37. [CrossRef]

50. Capozzi, V.; Makhoul, S.; Aprea, E.; Romano, A.; Cappellin, L.; Sanchez Jimena, A.; Spano, G.; Gasperi, F.; Scampicchio, M.; Biasioli, F. PTR-MS Characterization of VOCs Associated with Commercial Aromatic Bakery Yeasts of Wine and Beer Origin. Molecules 2016, 21, 483. [CrossRef]

51. Yang, S.C.; Lin, C.H.; Sung, C.T.; Fang, J.Y. Antibacterial activities of bacteriocins: Application in foods and pharmaceuticals. Front. Microbiol. 2014, 5, 241. [PubMed]

52. Bell, V.; Ferrão, J.; Pimentel, L.; Pintado, M.; Fernandes, T. One Health, Fermented Foods, and Gut Microbiota. Foods 2018, 7, 195. [CrossRef] [PubMed]

53. Mota de Carvalho, N.; Costa, E.M.; Silva, S.; Pimentel, L.; Fernandes, T.H.; Pintado, M.E. Fermented Foods and Beverages in Human Diet and Their Influence on Gut Microbiota and Health. Fermentation 2018, 4, 90. [CrossRef]

54. Ranadheera, C.S.; Vidanarachchi, J.K.; Rocha, R.S.; Cruz, A.G.; Ajlouni, S. Probiotic Delivery through Fermentation: Dairy vs. Non-Dairy Beverages. Fermentation 2017, 3, 67. [CrossRef]

55. Chen, L.; Zhang, J.; Suo, H.; Wang, W.; Wang, H.; Zhang, Y.; Hu, Q.; Zhao, X.; Li, J. Preventive Effects of Different Fermentation Times of Shuidouchi on Diphenoxylate-Induced Constipation in Mice. Foods 2019, 8, 86. [CrossRef] [PubMed]

56. Huang, Y.-C.; Wu, B.-H.; Chu, Y.-L.; Chang, W.-C.; Wu, M.-C. Effects of Tempeh Fermentation with Lactobacillus plantarum and Rhizopus oligosporus on Streptozotocin-Induced Type II Diabetes Mellitus in Rats. Nutrients 2018, 10, 1143. [CrossRef]

57. Pabich, M.; Materska, M. Biological Effect of Soy Isoflavones in the Prevention of Civilization Diseases. Nutrients 2019, 11, 1660. [CrossRef]

58. Verni, M.; Verardo, V.; Rizzello, C.G. How Fermentation Affects the Antioxidant Properties of Cereals and Legumes. Foods 2019, 8, 362. [CrossRef]

59. Ali, M.W.; Kim, I.-D.; Bilal, S.; Shahzad, R.; Saeed, M.T.; Adhikari, B.; Nabi, R.B.S.; Kyo, J.R.; Shin, D.-H. Effects of Bacterial Fermentation on the Biochemical Constituents and Antioxidant Potential of Fermented and Unfermented Soybeans Using Probiotic Bacillus subtilis (KCTC 13241). Molecules 2017, 22, 2200. [CrossRef] 
60. Michitaka, N.; Xiaohong, W.U.; Jer-Min, L.; Akihiko, K.; Michiteru, K.; Atsushi, T.; Toshitaka, O.; Toshihiko, O. Anti-Atherogenic Effects of Fermented Fresh Coffee Bean, Soybean and Rice Bran Extracts. Food Sci. Technol. Res. 2003, 9, 170-175.

61. Franco, R.; Navarro, G.; Martínez-Pinilla, E. Hormetic and Mitochondria-Related Mechanisms of Antioxidant Action of Phytochemicals. Antioxidants 2019, 8, 373. [CrossRef] [PubMed]

62. Zhou, H.; Li, X.; Shang, Y.; Chen, K. Radical Scavenging Activity of Puerarin: A Theoretical Study. Antioxidants 2019, 8, 590. [CrossRef] [PubMed]

63. de Camargo, A.C.; Favero, B.T.; Morzelle, M.C.; Franchin, M.; Alvarez-Parrilla, E.; de la Rosa, L.A.; Geraldi, M.V.; Maróstica Júnior, M.R.; Shahidi, F.; Schwember, A.R. Is Chickpea a Potential Substitute for Soybean? Phenolic Bioactives and Potential Health Benefits. Int. J. Mol. Sci. 2019, 20, 2644. [CrossRef] [PubMed]

64. Lim, S.; Seong, K.; Song, S.; Hwang, J.; Lee, B. Effect of rice bran and soybean fermented by Bacillus spp. on lipid profiles of liver, serum, and feces in rats fed high fat diet. J. Korean Soc. Appl. Biol. Chem. 2011, 54, 237-242. [CrossRef]

65. Kim, C.H.; Park, S.B.; Jeon, J.J.; Kim, H.S.; Kim, S.H.; Hong, E.C.; Kang, H.K. Effects of Dietary Supplementation of Fermented Rice Bran (FRB) or Fermented Broken Rice (FBR) on Laying Performance, Egg Quality, Blood Parameter, and Cholesterol in Egg Yolk of Hy-Line Brown Laying Hens. Korean J. Poult. Sci. 2017, 44, 235-243. [CrossRef]

66. Islam, J.; Koseki, T.; Watanabe, K.; Budijanto, S.; Oikawa, A.; Alauddin, M.; Goto, T.; Aso, H.; Komai, M.; Shirakawa, H. Dietary Supplementation of Fermented Rice Bran Effectively Alleviates Dextran Sodium Sulfate-Induced Colitis in Mice. Nutrients 2017, 9, 747. [CrossRef]

67. Saji, N.; Francis, N.; Schwarz, L.J.; Blanchard, C.L.; Santhakumar, A.B. Rice Bran Derived Bioactive Compounds Modulate Risk Factors of Cardiovascular Disease and Type 2 Diabetes Mellitus: An Updated Review. Nutrients 2019, 11, 2736. [CrossRef]

68. Gan, R.Y.; Li, H.B.; Gunaratne, A.; Sui, Z.Q.; Corke, H. Effects of Fermented Edible Seeds and Their Products on Human Health: Bioactive Components and Bioactivities. Compr. Rev. Food Sci. Food Saf. 2017, 16, 489-531. [CrossRef]

69. Henderson, A.J.; Ollila, C.A.; Kumar, A.; Borresen, E.C.; Raina, K.; Agarwal, R.; Ryan, E.P. Chemopreventive properties of dietary rice bran: Current status and future prospects. Adv. Nutr. 2012, 3, 643-653. [CrossRef]

70. Kuno, T.; Takahashi, S.; Tomita, H.; Hisamatsu, K.; Hara, A.; Hirata, A.; Kobayashi, H.; Mori, H. Preventive effects of fermented brown rice and rice bran against $\mathrm{N}$-nitrosobis (2-oxopropyl) amine-induced pancreatic tumorigenesis in male hamsters. Oncol. Lett. 2015, 10, 3377-3384. [CrossRef]

71. Yeap, S.K.; Beh, B.K.; Ali, N.M.; Mohd, Y.H.; Ho, W.Y.; Koh, S.P.; Alitheen, N.B.; Long, K. In vivo antistress and antioxidant effects of fermented and germinated mung bean. Biomed. Res. Int. 2014, 2014, 694842. [CrossRef] [PubMed]

72. Kim, D.; Kim, G.W.; Lee, S.H.; Han, G.D. Ligularia fischeri extract attenuates liver damage induced by chronic alcohol intake. Pharm. Biol. 2016, 54, 1465-1473. [CrossRef] [PubMed]

73. Phutthaphadoong, S.; Yamada, Y.; Hirata, A.; Tomita, H.; Hara, A.; Limtrakul, P.; Iwasaki, T.; Kobayashi, H.; Mori, H. Chemopreventive effect of fermented brown rice and rice bran (FBRA) on the inflammation-related colorectal carcinogenesis in ApcMin/+ mice. Oncol. Rep. 2010, 23, 53-59. [PubMed]

74. Kim, D.; Han, G.D. Ameliorating effects of fermented rice bran extract on oxidative stress induced by high glucose and hydrogen peroxide in 3T3-L1 adipocytes. Plant Foods Hum. Nutr. 2011, 66, 285-290. [CrossRef] [PubMed]

75. Casas, G.A.; Overholt, M.F.; Dilger, A.C.; Boler, D.D.; Stein, H.H. Effects of full fat rice bran and defatted rice bran on growth performance and carcass characteristics of growing-finishing pigs. J. Anim. Sci. 2018, 96, 2293-2309. [CrossRef]

76. Zare-Sheibani, A.A.; Arab, M.; Zamiri, M.J.; Rezvani, M.R.; Dadpasand, M.; Ahmadi, F. Effects of extrusion of rice bran on performance and phosphorous bioavailability in broiler chickens. J. Anim. Sci. Technol. 2015, 57, 26. [CrossRef] [PubMed]

77. Law, B.M.H.; Waye, M.M.Y.; So, W.K.W.; Chair, S.Y. Hypotheses on the Potential of Rice Bran Intake to Prevent Gastrointestinal Cancer through the Modulation of Oxidative Stress. Int. J. Mol. Sci. 2017, 18, 1352.

78. Rahman, M.; Yang, D.K.; Kim, G.B.; Lee, S.J.; Kim, S.J. Nigella sativa seed extract attenuates the fatigue induced by exhaustive swimming in rats. Biomed. Rep. 2017, 6, 468-474. [CrossRef] 
79. Sivamaruthi, B.S.; Kesika, P.; Chaiyasut, C. A Comprehensive Review on Functional Properties of Fermented Rice Bran. Pharmacogn. Rev. 2018, 12, 218. [CrossRef]

80. Seo, Y.K.; Jung, S.H.; Song, K.Y.; Park, J.K.; Park, C.S. Anti-photoaging effect of fermented rice bran extract on UV-induced normal skin fibroblasts. Eur. Food Res. Technol. 2010, 231, 163-169. [CrossRef]

81. Cheng, J.; Choi, B.; Yang, S.H.; Suh, J. Effect of Fermentation on the Antioxidant Activity of Rice Bran by Monascus pilosus KCCM60084. J. Appl. Biol. Chem. 2016, 59, 57-62. [CrossRef]

82. Sivamaruthi, B.S.; Kesika, P.; Prasanth, M.I.; Chaiyasut, C. A Mini Review on Antidiabetic Properties of Fermented Foods. Nutrients 2018, 10, 1973. [CrossRef] [PubMed]

83. Wei, Y.S.; Wung, B.S.; Lin, Y.C.; Hsieh, C.W. Isolating a cytoprotective compound from Ganoderma tsugae: Effects on induction of Nrf-2-related genes in endothelial cells. Biosci. Biotechnol. Biochem. 2009, 73, 1757-1763. [CrossRef] [PubMed]

84. Choi, C.H.; An, J.E.; Jeong, H.W. Study of Fermentation Extract Made from Rice Bran and Dendropanax on the Whitening Effects in B16F10 Cell Line. J. Physiol. Pathol. Korean Med. 2016, 30, 301. [CrossRef]

85. Galicia-Moreno, M.; Rosique-Oramas, D.; Medina-Avila, Z.; Álvarez-Torres, T.; Falcón, D.; Higuera-de la, T.F.; Béjar, Y.L.; Cordero-Pérez, P.; Muñoz-Espinosa, L.; Pérez-Hernández, J.L.; et al. Behavior of Oxidative Stress Markers in Alcoholic Liver Cirrhosis Patients. Oxid. Med. Cell Longev. 2016, 2016, 9370565. [CrossRef]

86. Ayala, A.; Muñoz, M.F.; Argüelles, S. Lipid peroxidation: Production, metabolism, and signaling mechanisms of malondialdehyde and 4-hydroxy-2-nonenal. Oxid. Med. Cell Longev. 2014, 2014, 360438. [CrossRef]

87. Chen, Y.; Singh, S.; Matsumoto, A.; Manna, S.K.; Abdelmegeed, M.A.; Golla, S.; Murphy, R.C.; Dong, H.; Song, B.J.; Gonzalez, F.J.; et al. Chronic Glutathione Depletion Confers Protection against Alcohol-induced Steatosis: Implication for Redox Activation of AMP-activated Protein Kinase Pathway. Sci. Rep. 2016, 6, 29743. [CrossRef]

88. Li, S.; Tan, H.-Y.; Wang, N.; Zhang, Z.-J.; Lao, L.; Wong, C.-W.; Feng, Y. The Role of Oxidative Stress and Antioxidants in Liver Diseases. Int. J. Mol. Sci. 2015, 16, 26087-26124. [CrossRef]

89. Manzo-Avalos, S.; Saavedra-Molina, A. Cellular and mitochondrial effects of alcohol consumption. Int. J. Environ. Res. Public. Health. 2010, 7, 4281-4304. [CrossRef]

90. Hoek, J.B.; Cahill, A.; Pastorino, J.G. Alcohol and mitochondria: A dysfunctional relationship. Gastroenterology 2002, 122, 2049-2063. [CrossRef]

91. Klaunig, J.E.; Kamendulis, L.M.; Hocevar, B.A. Oxidative stress and oxidative damage in carcinogenesis. Toxicol. Pathol. 2010, 38, 96-109. [CrossRef] [PubMed]

92. Vázquez-Martínez, O.; Valente-Godínez, H.; Quintanar-Stephano, A.; Gasca-Martínez, D.; López-Cervantes, M.L.; Palma-Tirado, L.; de Jesús Guerrero-Carrillo, M.; Pérez-Solís, M.; Díaz-Muñoz, M. Reduced Liver Lipid Peroxidation in Subcellular Fractions Is Associated with a Hypometabolic State in Rats with Portacaval Anastomosis. Oxid. Med. Cell Longev. 2019, 2019, 4565238. [CrossRef] [PubMed]

93. Srilaxmi, P.; Sareddy, G.R.; Kavi, K.P.B.; Setty, O.H.; Babu, P.P. Protective efficacy of natansnin, a dibenzoyl glycoside from Salvinia natans against $\mathrm{CCl} 4$ induced oxidative stress and cellular degeneration in rat liver. BMC Pharmacol. 2010, 10, 13. [CrossRef] [PubMed]

94. Raza, H.; John, A.; Howarth, F.C. Increased oxidative stress and mitochondrial dysfunction in zucker diabetic rat liver and brain. Cell Physiol. Biochem. 2015, 35, 1241-1251. [CrossRef]

95. Lamid, M.; Al-Arif, M.A.; Amin, M.; Warsito, S.H. Decreasing triglyceride, LDL—c and increasing HDL-c contents in broiler meat by partial replacement of commercial feed with fermented rice bran and turmeric flour. Biocatal. Agric. Biotechnol. 2020, 23, 101450. [CrossRef]

96. Park, N.Y.; Rico, C.W.; Lee, S.C.; Kang, M.Y. Comparative effects of doenjang prepared from soybean and brown rice on the body weight and lipid metabolism in high fat-fed mice. J. Clin. Biochem. Nutr. 2012, 51, 235-240. [CrossRef]

97. Govindarajan, S.; Vellingiri, K. Effect of Red Yeast Rice and Coconut, Rice Bran or Sunflower Oil Combination in Rats on Hypercholesterolemic Diet. J. Clin. Diagn. Res. 2016, 10, BF05-BF07. [CrossRef]

(C) 2020 by the authors. Licensee MDPI, Basel, Switzerland. This article is an open access article distributed under the terms and conditions of the Creative Commons Attribution (CC BY) license (http://creativecommons.org/licenses/by/4.0/). 